University of Pennsylvania Carey Law School

Penn Law: Legal Scholarship Repository

Faculty Scholarship at Penn Law

$5-30-2008$

\title{
Patent Deception in Standard Setting: The Case for Antitrust Policy
}

Herbert J. Hovenkamp

University of Pennsylvania Carey Law School

Follow this and additional works at: https://scholarship.law.upenn.edu/faculty_scholarship

Part of the Antitrust and Trade Regulation Commons, Business Law, Public Responsibility, and Ethics Commons, Intellectual Property Law Commons, Law and Economics Commons, and the Technology and Innovation Commons

\section{Repository Citation}

Hovenkamp, Herbert J., "Patent Deception in Standard Setting: The Case for Antitrust Policy" (2008). Faculty Scholarship at Penn Law. 1774.

https://scholarship.law.upenn.edu/faculty_scholarship/1774

This Article is brought to you for free and open access by Penn Law: Legal Scholarship Repository. It has been accepted for inclusion in Faculty Scholarship at Penn Law by an authorized administrator of Penn Law: Legal Scholarship Repository. For more information, please contact PennlawIR@law.upenn.edu. 


\title{
Patent Deception in Standard Setting: the Case for Antitrust Policy
}

\author{
Herbert Hovenkamp ${ }^{1}$
}

\section{Introduction: Patent Continuations and Divisionals}

Many patent applications are rejected upon initial submission, but they are almost never rejected with absolute finality. Further, subsequent to filing its original application a patent applicant might wish to write an application with broader or somewhat different claims, or perhaps add claims that were not made in the original application. Or it may wish to rewrite claims that had been rejected in the original application. A patent "continuation" is an application for additional claims made on a patent that was previously applied for.

A "divisional" application is a particular type of patent continuation in which the original patent application lacked "unity." "Unity of invention" is said to be a prerequisite for patenting because a patent may relate to only one invention, or perhaps to a group of closely related inventions. When a patent is rejected for lack of unity the patentee may then file a "divisional" application for spin-off of second, third, or subsequent inventions. ${ }^{2}$ The PTO may reject a patent altogether for lack of unity, or it may grant a patent on one invention while leaving the patentee free to file later divisional

${ }^{1}$ Ben V. \& Dorothy Willie Professor of Law, University of lowa.

${ }^{2}$ The Patent Act provides for continuations in 35 U.S.C. ' 132. On possible abuses, see Mark A. Lemley and Kimberly A. Moore, Ending Abuse of Patent Continuations, 84 Boston Univ. L.Rev. 63 (2004); Christina Bohann and Herbert Hovenkamp, IP and Antitrust: Reformation and Harm, B.C.L.Rev. (2010) (in press), available at http://papers.ssrn.com/sol3/cf_dev/AbsByAuth.cfm?per_id=106256

In such cases the original application is called the "parent." Typically the patentee will claim one invention off the parent application, and then begin a process of filing additional "divisional" applications for other inventions covered by the patent. When these later divisional applications are granted the priority date of those patents ordinarily relates back to the date of the parent. Further, the claims language in the subsequent divisional applications need not be identical with that in the parent and can cover technology that was not actually contemplated in the parent. 
applications for other inventions that were arguably covered in the original application.

Under generally accepted patent practices in the United States, when a subsequent continuation or divisional application is granted the subsequent patent "relates back" to the date of the original patent application, and will typically retain the original application's priority over rival filings.

While patent continuations are an accepted part of the arcane process under which patents are granted, they can also bring considerable anticompetitive abuse. ${ }^{3}$ In particular, the continuation process makes it possible for a patentee to write updated claims designed to exclude a rival's invention that has been placed on the market subsequent to the date of the original application. For example, a patent applicant might file an overly broad patent application in 2000. In 2001 someone else might place a new invention on the market. The 2000 applicant might then file a continuation or divisional application expressly designed to cover the 2001 invention and claim priority over it, even though the 2001

\footnotetext{
${ }^{3}$ In 2007 the PTO promulgated amendments to its procedures that were intended to limit the number of continuation and divisional applications relating to a particular parent patent. However, a federal district court struck these amendments down as exceeding the PTO's rule making authority. Tafas v. Dudas, 511 F.Supp.2d 652 (E.D.Va. 2007). As the court described the proposed rules:

Under the old system, an applicant could file an unlimited number of continuing applications, RCEs [request for continued examination], and claims. The Final Rules modify that system in the several ways. First, Final Rules 78 and 114 allow an applicant to file two continuation or continuation-in-part applications, plus a single RCE, after an initial application as a matter of right. If the applicant wants to engage in further prosecution, a third continuation or continuation-in-part application or a second RCE can be filed with a "petition and showing" that explains why the amendment, argument, or evidence could not have been presented in one of the previously-filed applications.
}

Id. at 657-658. See also Tafas v. Dudas, F.Supp.2d 2008 WL 859467 (E.D.Va. Apr. 1, 2008) (rules promulgated by PTO were substantive in character and exceeded PTO's rule making authority; granting motion for summary judgment).

Note that a provision included in the House version of the 2007 Patent Reform Act at the time of this writing would overrule Tafas by explicitly giving the PTO rule making authority. 
inventor had no reasonable way of knowing that its invention was subject to an "earlier" patent. If a divisional patent is later granted in, say, 2002, its priority date will relate back to the 2000 patent. ${ }^{4}$ The harmfulness of this process is exacerbated by the fact that the publication requirements for pending patent applications in the United States are very weak, requiring publication only 18 months after filing, and even then only if the application is not subject to foreign filing as well. ${ }^{5}$ Even if the application is published a rival cannot know with certainty what its claims will be until final approval.

The possibility of such abuses reveals one of the more deficient aspects of the patent system's failure to provide adequate notice to inventors, as discussed previously. ${ }^{6}$ While patents may be

\footnotetext{
${ }^{4}$ Lemley and Moore cite these cases as examples, with these parentheticals:

[In] Chiron Corp. v. Genentech, Inc., 268 F. Supp. 2d 1148 (E.D. Cal. 2002), the plaintiff filed a patent application covering monoclonal antibodies in 1984, a time when the technology was in its infancy. It kept various applications pending in the PTO until 1999, when it drafted new claims designed to cover not just monoclonal antibodies as they were understood in 1984, but new types of antibodies developed in the intervening 15 years, including those invented by the defendant. Id. at 1151-52. Another example is Gentry Gallery, Inc. v. Berkline Corp., 134 F.3d 1473 (Fed. Cir. 1998). The patentee there amended his claims to a reclining chair to claim placing the controls for that chair in a position he never thought of, but saw for the first time on his competitor's product. Id. at 1479 ("Sproule admitted at trial that he did not consider placing the controls outside the console until he became aware that some of Gentry's competitors were so locating the recliner controls.").
}

See Lemley and Moore, Ending Abuse, note 2, 84 Boston Univ.L.Rev. at 7677.

${ }^{5}$ See 35 U.S.C. ' 122(b).

${ }^{6}$ See 3 Phillip E. Areeda \& Herbert Hovenkmap, Antitrust Law $\llbracket 704 a, b$ (3d ed. 2008). See James Bessen and Michael J. Meurer, Patent Failure: How Judges, Bureaucrats, and Lawyers Put Innovators at Risk 62-65 (2008), noting, inter alia, that the number of continuing applications had increased seven-fold in the previous twenty years. Further,

Applicants can change claim language in patents without updating the published applications. The final claim language is published only after the patent is issued, and the gap between application date and issuance is growing. Moreover, publication does little to prevent patent applicants from introducing unanticipated new claims via continuing applications. 
a species of property, they are property with a woefully inadequate system for recording titles and making them public prior to someone else's investment decision. To the extent a patentee can manipulate the continuation or divisional process to write patent claims on the existing inventions of other inventors who did not have adequate prior notice of them, the policy reduces rather than increases the incentive to innovate. An inventor might do a thorough patent search and not find any prior claim on his invention, but later be made the subject of an infringement suit on the basis of a continuing or divisional application that was filed later but that earns the priority of the original patent application.

Nevertheless, there is probably little room for application of the antitrust laws, given that the Federal Circuit has expressly approved the use of continuation and divisional applications to write updated claims on a competitor's existing products or technology. The notice and publication provisions are part of the law as well. ${ }^{7}$ While we believe such an approach to the giving of notice deters rather than promotes innovation, the fact is that conduct approved by

Id. at 63 .

Cir. 1988):

${ }^{7}$ See Kingsdown Medical Consultants v. Hollister, 863 F.2d 867, 874 (Fed.

$[T]$ here is nothing improper, illegal or inequitable in filing a patent application for the purpose of obtaining a right to exclude a known competitor's product from the market; nor is it in any manner improper to amend or insert claims intended to cover a competitor's product the applicant's attorney has learned about during the prosecution of a patent application. Any such amendment or insertion must comply with all statutes and regulations, of course, but, if it does, its genesis in the marketplace is simply irrelevant and cannot of itself evidence deceitful intent. To be sure, applicants do not simply have carte blanche to rewrite their claims. The new claims must find adequate support in the original application. If not, the patent will be invalid for lack of enablement or written description, or alternatively, the new claims will be considered "new matter" invented only as of the date the claims were added. If the patentee can find some support in the original patent application for the current claims, however, she can obtain legal rights over ideas that (at least in that form) never occurred to her until she saw what others were already doing.

Accord State Indus., Inc. v. A.O. Smith Corp., 751 F.2d 1226, 1235 (Fed. Cir. 1985). See Lemley article, note 1, 84 Boston Univ. L.Rev. at 77-78. 
law cannot form the basis of an antitrust claim when the patentee later files an infringement action based on such an after-acquired right.

\section{Misrepresentation and Subsequent Assertion of Continuation Claims.}

While it is lawful to write patent continuations on the existing technology of rivals, the standard-setting misrepresentation cases add an additional element that can implicate the antitrust laws. To take the simplest example, suppose that a firm has written a patent application that is subject to further continuations or divisional applications. During this period its application is unpublished. It then participates in a standard setting organization that is developing new technological standards. While participating in this fashion it also surreptitiously writes continuation claims that are calculated to cover the technology that the standard setting organization is developing. After the participants have committed themselves to the standardized technology it exposes its new patents, whose priority dates back to the original patent, and insists on royalties from all participants. Given the extent of their investment they have little choice but to pay.

The Rambus case involved a research company that was in the business of patenting designs for computer memory technology and licensing these to memory chip manufacturers. In 1990 Rambus had filed a single patent application, which the PTO found to describe multiple inventions, thus permitting Rambus to file numerous "divisional" applications derived from the original application. During the next decade the PTO granted some one dozen different patents based on these divisional applications. These applications, which ran through 1999, were given a 1990 priority date based on the original patent application. In an extremely fast moving technology market such as that for computer memory this created at least an opportunity that subsequent divisionals could have included claims for technology not reasonably contemplated in the 1990 application. However, as noted previously, continuation applications of this sort are completely proper under patent policy even if the applicant writes the subsequent divisional applications expressly to cover inventions developed subsequent to the original application. The relation back doctrine means that the patent will cover them. Any antitrust violation must consist not in writing the 
subsequent divisional applications in order to cover the technology developed by others, but in the misrepresentations to and participation in the standard-setting process.

One significant feature of computer memory chips is that they must be compatible with a variety of computers. This requires that chip producers develop a common set of standards for performance and interoperability. The Electronic Industries Association, a trade association including memory chip manufacturers, developed the Joint Electron Devices Engineering Council (JEDEC) whose assignment was continuously to develop and maintain interchangeability standards for such chips. Rambus was a member of JEDEC during the early 1990s, after it had filed its original patent application, and when the standards for SDRAM ("synchronous dynamic random access memory"). During that period the members of JEDEC knew about original 1990s patent application, and also knew that one divisional patent under that application had been injured. However, Rambus did not disclose that it had additional divisional applications in process. According to the FTC Rambus also took advantage of its membership in JEDEC to formulate additional divisional applications written on the very technology that JEDEC was in the process of developing, all of which would obtain the original 1990 priority date under PTO continuance rules.

In 1995 members of JEDEC began to become suspicious that Rambus had undisclosed patent claims or was in the process of perfecting new ones. Rambus refused to respond to a request to disclose these rights and then withdrew from JEDEC in 1996.

In a subsequent patent infringement lawsuit that Rambus brought against a JEDEC chip maker the Federal Circuit found the patents in question to be valid and infringed. While Rambus may or may not have acted fraudulently, computer chip makers who applied the JEDEC standards would not necessarily have to infringe any of Rambus' patents. The court also faulted JEDEC for failing to have an unambiguous standard about disclosure of pending patent applications:

In this case there is a staggering lack of defining details in the EIA/JEDEC patent policy. When direct competitors participate in an open standards committee, their work necessitates a written patent policy with clear guidance on the committee's 
intellectual property position. A policy that does not define clearly what, when, how, and to whom the members must disclose does not provide a firm basis for the disclosure duty necessary for a fraud verdict. Without a clear policy, members form vaguely defined expectations as to what they believe the policy requires-whether the policy in fact so requires or not. JEDEC could have drafted a patent policy with a broader disclosure duty. It could have drafted a policy broad enough to capture a member's failed attempts to mine a disclosed specification for broader undisclosed claims. It could have. It simply did not.

While the decision raised no antitrust issues, the court did opine that a rule creating a fiduciary duty on the part of JEDEC participants to disclose their patent applications would raise a risk of collusion. ${ }^{9}$

A dissenter saw the fraud issue quite differently:

Rambus attended its first JEDEC meeting in December 1991 and became a member in February 1992. At the time Rambus joined JEDEC, it had several pending patent applications derived from the [1990] patent application, which has spawned more than a thousand claims in dozens of continuation and divisional applications. Rambus also had a specific plan for using its pending patent applications against anyone using the SDRAM standard....

Rambus did not, in fact, inform anyone at JEDEC about its pending patent applications by the end of 1992. Instead, Rambus continued to attend JEDEC meetings for three more

\footnotetext{
${ }^{8}$ Rambus, Inc. v. Infineon Technologies, 318 F.3d 1081, 1102-1103 (Fed. Cir. 2003), cert. denied, 540 U.S. 874 (2003).

${ }^{9}$ Id. at 1096 n.7, 1102. On this point, see J. Gregory Sidak, Patent Holdup and Oligopsonistic Collusion in Standard Setting Organizations (Jan. 9, 2008), available at http://papers.ssrn.com/so/3/papers.cfm?abstract_id=1081997 (suggesting that the threat of oligopsony if standard setters are permitted to insist on particular royalty commitments in advance could be as great or greater than the threat of patent holdup royalties). See also Damien Gerardin \& Anne LayneFarrar, The Logic and Limits of Ex Ante Competition in a Standard Setting Environment, 3 Competition Pol'y Int'l 79 (2007). Contrast Mark A. Lemley \& Carl Shapiro, Patent Holdup and Royalty Stacking, 85 Tex.L.Rev. 1991 (2007).
} 
years, watching the SDRAM standard evolve and then amending its patent applications to try to cover features of the standard. Richard Crisp, Rambus's JEDEC representative, testified at trial about how "Rambus was intentionally drafting claims to intentionally cover the JEDEC SDRAMs...."

The record is replete with additional and specific instances of Rambus employees attending JEDEC meetings, taking notes of what was discussed, identifying instances where Rambus already had claims covering what was discussed, and then seeking claims to cover what they learned at the JEDEC meetings. Yet Rambus "did not tell the people at JEDEC that what they were proposing for standardization infringed [its] patents." 10

Deception is ordinarily a business tort that only rarely raises serious ' 2 issues. ${ }^{11}$ Because of the lack of transparency in the patent application process, however, deception about one's patents can exclude, particularly when others make irreversible technological commitments based on a false belief that the technology in question was unpatented. The issue arises mainly in the context of multifirm standard setting in which a participant lies, provides incomplete information, or simply keeps silent about patents that it is in the process of perfecting. The result can be adoption of this firm's technology to the exclusion of another firm whose technology would have been chosen had the true facts been known; or adoption of a firm's technology under the mistaken impression that it was in the public domain.

While active misrepresentations are reprehensible, silence is typically a problem only when there is a duty to speak. The clearest case for exclusionary conduct in the standard setting process arises when (1) the defendant was a willing participant and the standard setting organization ("SSO") has a clearly communicated policy of requiring the disclosure of patents and patent applications as a condition of participation; and (2) the failure to disclose results in the adoption of the defendant's technology even though another

${ }^{10} 318$ F.3d at 1108.

${ }^{11}$ See 3B Phillip E. Areeda \& Herbert Hovenkamp, Antitrust Law $₫ 782$ (3d ed. 2008). 
technology would have been preferred had it been known that the defendant's technology was not in the public domain. One difference between a government action and a private action is that the private firm seeking damages would have to show that a different technology would have been adopted or lower royalties obtained; otherwise there would be no competitive harm.

As the FTC characterized this conduct in its subsequent case against Rambus, ${ }^{12}$ while actively participating in JEDEC standard setting discussions,

${ }^{12}$ Rambus, Inc., 2006 WL 2330117, 2006-2 Trade Cas. 975364 (FTC, Aug. 2, 2006), rev'd, 522 F.3d 456 (D.C.Cir. 2008) (To the extent it is relevant, HH was consulted by the defendant after the FTC's remedial order was entered). See also Union Oil Co. of Calif. (Unocal), __ F.T.C. _ , 5 Trade Reg. Rep. \15618 (FTC, July 6 , 2004) (finding liability for misrepresentations made to a state agency in the process of promulgating standards; see $\{203 f 5$; the principal arguments involved the Noerr immunity for communications to the government).

And see Hynix Semiconductor Inc. V. Rambus, Inc., 527 F.Supp.2d 1084 (N.D.Cal. 2007) (refusing to strike pre-trial jury demand with respect to claim that Rambus engaged in a course of conduct involving abuse of patent rights in violation of ' 2 ; suggesting that litigation to enforce a valid patent might be part of a scheme that is unlawful overall; applying Federal Circuit law and concluding that that Circuit would apply a "causal connection" test:

before otherwise protected litigation can be a part of an "anticompetitive scheme" claim, the court must first find that the other aspects of the scheme independently produce anticompetitive harms. Once this step has been established, the court should ask whether the accused patent litigation was causally connected to these anticompetitive harms. If yes, an antitrust plaintiff may then include good faith patent litigation as part of the anticompetitive scheme.

(disagreeing with Herbert Hovenkamp, Mark D. Janis, Mark A. Lemley, \& Christopher Leslie, IP and Antitrust $\$ 11.4 f$ (2d ed. 2010), which would segregate the patent infringement action, considering it alone, and per antitrust liability only if the litigation is a sham.

The court then found a sufficient "scheme" in these allegations:

The Manufacturers have alleged that Rambus participated in a standardssetting organization, understood its intellectual property disclosure policy, withheld information about its patent applications, waited until the industry was irreversibly "locked in" to the standard, and then began a litigation campaign to extract royalties.

527 F.Supp.2d at 1098. At this writing Rambus has won on its patent infringement claims in a jury trial. 
Rambus refused to disclose the existence of its patents and applications, which deprived JEDEC members of critical information as they worked to evaluate potential standards. ${ }^{13}$ Rambus took additional actions that misled members to believe that Rambus was not seeking patents that would cover implementations of the standards under consideration by JEDEC. Rambus also went a step further: ${ }^{14}$ through its participation in JEDEC, Rambus gained information about the pending standard, and then amended its patent applications to ensure that subsequently-issued patents would cover the ultimate standard. Through its successful strategy, Rambus was able to conceal its patents and patent applications until after the standards were adopted and the market was locked in. Only then did Rambus reveal its patents -- through patent infringement lawsuits against JEDEC members who practiced the standard.

The result, according to the FTC, was anticompetitive exclusion resulting in:

increased royalties; increased prices for memory products compliant with JEDEC standards; decreased incentives to produce memory using JEDEC-compliant memory technology; and decreased incentives to participate in, and rely on, standard-setting organizations and activities.

${ }^{13}$ The FTC complaint alleged that Rambus deceived JEDEC's members by concealing the facts that it:

was actively working to develop, and did in fact possess, a patent and several pending patent applications that involved specific technologies proposed for and ultimately adopted in the relevant [JEDEC] standards. By concealing this information -- in violation of JEDEC's own operating rules and procedures -- and through other bad-faith, deceptive conduct....

${ }^{14}$ According to the allegations Rambus created the:

"materially false and misleading impression that it possessed no relevant intellectual property rights" and that it had no plans to enforce any intellectual property rights that might later become relevant, leaving a materially misleading impression of its intellectual property ownership and plans. 
The FTC concluded that Rambus violated ' 5 of the Federal Trade Commission Act by engaging in exclusionary conduct that violated ' 2 of the Sherman Act.

The Commission defined anticompetitive exclusionary conduct as "conduct other than competition on the merits -- or other than restraints reasonably 'necessary' to competition on the merits -that reasonably appear[s] capable of making a significant contribution to creating or maintaining monopoly power."15 It concluded that intentional deception of a standard setting organization in order to acquire patents to shared technology was not competition on the merits. ${ }^{16}$ The opinion also noted that, given the FTC's broader role in consumer protection, it had developed "special expertise" in the recognition of deceptive conduct. ${ }^{17}$ According to its 1983 Policy Statement:

for conduct to be found deceptive, there must have been a "misrepresentation, omission or practice" that was "material" in that it was likely to mislead "others acting reasonably under the circumstances" and thereby likely to affect their "conduct or decision[s]." Thus, in order to determine whether conduct (including a course of conduct) is deceptive, we must consider "the circumstances" in which the alleged "misrepresentation, omission or practice" occurred. We analyze the legal circumstances, factual circumstances, and nature of the

F.T.C. , 2006-2 Trade Cas. $₫ 75364$ at 105,486 quoting 3 Phillip E. Areeda \& Herbert Hovenkamp, Antitrust Law $₫ 651 \mathrm{f}$ at 83-84 (2d ed. 2002). The Commission also quoted the Aspen Skiing formulation that "If a firm has been 'attempting to exclude rivals on some basis other than efficiency,' it is fair to characterize its behavior as predatory." Aspen Skiing Co. v. Aspen Highlands Skiing Corp., 472 U.S. 585, 605 (1985) (quoting Robert H. Bork, The Antitrust Paradox 138 (1978).

${ }^{16}$ The Commission cited numerous decisions for the proposition that deception can, in appropriate circumstances, constitute unreasonable exclusionary conduct, including: Conwood Co., LP v. U.S. Tobacco Co., 290 F.3d 768 (6th Cir. 2002), cert. denied, 537 U.S. 1148 (2003); United States v. Microsoft Corp., 253 F.3d 34, 76-77 (D.C. Cir. 2001), cert. denied, 534 U.S. 952 (2001); Caribbean Broad. Sys. Ltd. v. Cable \& Wireless PLC, 148 F.3d 1080, 1087 (D.C. Cir. 1998); International Travel Arrangers, Inc. v. Western Airlines, 623 F.2d 1255, 1262-63, 1270 (8th Cir.), cert. denied, 449 U.S. 1063 (1980).

17 F.T.C. at 2006-2 Trade Cas. $₫ 75364$ at 105,486. 
conduct itself in assessing Rambus's conduct. ${ }^{18}$

However, before simple deception as defined for purposes of consumer protection law could rise to a Sherman ' 2 violation, two additional elements were needed:

First, under the Policy Statement, the respondent's state of mind is irrelevant in determining whether the respondent engaged in deceptive conduct under Section 5. Under Section 2 , however, the defendant must act "willfully" in acquiring or maintaining monopoly power. Thus, for Rambus's allegedly deceptive course of conduct to be actionable under the Sherman Act, Rambus must have acted "willfully," as opposed to inadvertently or even negligently.

Second, the Policy Statement does not require proof of competitive harm for a respondent's conduct to be deemed deceptive under Section 5. However, under Section 2, in order to be condemned as "exclusionary," defendant's conduct must harm the competitive process, and that anticompetitive harm must outweigh the conduct's procompetitive benefits, if any. Thus, for Rambus's alleged deceptive course of conduct to be actionable under Section 2, the conduct must have an anticompetitive effect that outweighs any procompetitive benefit. $^{19}$

The Commission also noted that while deception is unlikely to violate ' 2 in "competitive environments," under the right circumstances it can cause competitive harm. Here,

deceptive conduct could have caused lasting competitive harm by obscuring crucial information, known only to one industry member, until it was too late to counteract the consequences. In this context, we cannot stress too strongly the importance we place on the fact that the challenged conduct occurred in the context of a standard-setting process

${ }^{18}$ Id. at 105,487 , quoting Federal Trade Commission, Policy Statement on Deception (1983), reprinted in 4 Trade Reg. Rep. (CCH) $₫ 13,205$ at 20,911-12.

${ }^{19}$ Rambus, F.T.C. at , 2006-2 Trade Cas. $\ 75364$ at p. 105, 487 (footnotes omitted). 
in which members expected each other to act cooperatively. We recognize that standard setting of the type sponsored by JEDEC potentially yields significant efficiencies -- especially when the standards facilitate interoperability among various components, to the likely benefit of industry participants as well as consumers. Although standard setting displaces the normal process of selection through market-based competition -- by which, without any agreement, the purchasing decisions of customers determine which interoperable combinations of products and technologies ultimately will survive -- the efficiency benefits of consensus standard setting easily can outweigh that loss of competition.

... Additionally, unlike misleading statements made in advertising -- which can be corrected quickly by a competitor's counter-advertising -- there are fewer "quick fixes" available to correct the competitive harm caused by deception in the SSO ["standard setting organization"] context, once a standard has been chosen and the industry has become locked in. If exclusionary conduct reduces or destroys the efficiencies to be gained through consensus standard setting, it may cause considerable harm to competition. If the anticompetitive harm exceeds any remaining efficiencies, standard setting is no longer beneficial on balance. ${ }^{20}$

To this the FTC added:

We do not hold, and our decision should not be read to mandate, that all SSOs should require disclosure of relevant intellectual property. An SSO may choose not to require such disclosures. If, however, an SSO does require such disclosures, then non-disclosure -- followed by adoption of a standard incorporating the intellectual property, and royalty demands against those practicing the standard -- may be considered a material omission and may constitute deceptive conduct under Section 5. If an SSO chooses not to require such disclosures, SSO members still are not free to lie or to

${ }^{20}$ Rambus, note 12 at $105,488-105,489, \ldots$ F.T.C. at _ citations omitted). The Commission cited Allied Tube \& Conduit Corp. v. Indian Head, Inc., 486 U.S. 492 (1988), as a decision in which the Supreme Court had been willing to base antitrust liability on manipulation of the standard setting process. 
make affirmatively misleading representations. In either case, whether the SSO requires disclosure should be judged not only by the letter of its rules, but also on how the rules are interpreted by its members, as evidenced by their behavior as well as by their statements of what they understand the rules to be. ${ }^{21}$

Speaking of anticompetitive effects, the FTC explained:

In order to assess fully the circumstances under which the alleged deception occurred, we also must understand the nature of the allegedly deceptive course of conduct, which combined the acquisition and exploitation of patents with a cooperative standard-setting process. A patent holder's market power may be materially enhanced once the patented technology is incorporated into a standard, as alternatives become less attractive relative to the chosen technology and less able to constrain its price. For this reason, Rambus's alleged course of conduct, if established, could be especially pernicious to the competitive process.

An SSO may elect to require disclosure of patent positions before standardization decisions are made, because this enables SSO participants to make their choices with more complete knowledge of the consequences -- including the potential that those practicing the standard may be liable for patent infringement, unless they negotiate licenses and pay royalties. If the SSO members prefer a given technology, notwithstanding the prospect of royalties, they can vote to incorporate it into the standard. If, in light of likely royalty payments, members prefer an alternative technology, they can vote against inclusion of the patented technology. ${ }^{22}$

\footnotetext{
${ }^{21}$ Rambus, id. at $105,489, \ldots$ F.T.C. at

${ }^{22}$ Rambus, p. 105,489, __ F.T.C. at __. Compare the sharply contrasting approach Golden Bridge Technology, Inc. v. Nokia, Inc., 416 F.Supp.2d 525 (E.D. Tex. 2006), finding the possibility of an unlawful conspiracy where the standard setting association knew about the technology and refused to incorporate it into its standard, with the result that the plaintiff was not able to charge royalties. Subsequently, however, that court dismissed the antitrust complaint after finding no conspiracy. See 2007 WL 2688487 (E.D.Tex. Sep. 11, 2007).
} 
The Commission found evidence that JEDEC expected disclosure of patents and patent application by its members, that Rambus participated in discussions concerning the adoption of standards while knowing of these requirements, and that it nevertheless concealed its patent applications from the standard setting group. It also found that Rambus' various presentations to the standard-setting group were not sufficient to give the group reasonable notice that Rambus claimed the patent rights in question or would assert them in the future.

On causation, the Commission also found ample evidence linking Rambus' conduct to JEDEC's adoption of standards incorporating Rambus' IP rights, and also linking that adoption to the creation of Rambus' monopoly power. On the first, the Commission observed that alternative technologies had been available to JEDEC, which they could have adopted had they known about Rambus' claimed patent rights. ${ }^{23}$ On the second, it found strong evidence that ram chip technology was likely to gravitate around a single standard, given the strong need for interoperability with complementary products. ${ }^{24}$ The Commission also noted that:

Exclusionary conduct need not be the exclusive cause of the monopoly position. In an equitable enforcement action, it is sufficient that the exclusionary conduct "reasonably appear[s] capable of making a significant contribution to creating or maintaining monopoly power." ${ }^{25}$

The Commission also rejected Rambus' argument that JEDEC would have adopted its technologies even had full disclosure been made, because these technologies were superior to alternatives even if a royalty had to be paid for them. ${ }^{26}$

Rambus also claimed that no monopoly power was created by the misrepresentations because there was no "lock in" -- i.e.,

\footnotetext{
${ }^{23}$ See Rambus, note 12 at 105,509, F.T.C. at

${ }^{24}$ See $105,509-510$, F.T.C. at

${ }^{25}$ Ibid., quoting 3 Anitrust Law $\llbracket 651 \mathrm{f}$ (2d ed), and also discussing Microsoft,
} note 16, 253 F.3d at 79.

${ }^{26}$ Rambus, note 12 at 105,511 , F.T.C. at 
participant manufacturers were free to select alternative standards that did not infringe Rambus' IP rights. The Commission observed that the relevant time for considering that claim was when the nondisclosures or misrepresentations became known and Rambus' patent rights revealed. By that time, the Commission concluded, manufacturers had made significant sunk investments in the Rambus technology.

The D.C. Circuit reversed the Commission, rejecting the notion that "deceit merely enabling a monopolist to charge higher prices than it otherwise could have charged" constituted an act of monopolization. ${ }^{27}$ The court observed that Rambus' original 1990 patent application included 150 claims and that thereafter Rambus split the application into the original and 10 divisionals, as continuing applications. $^{28}$ It was during the period that it was developing these ongoing applications that Rambus worked with the JEDEC standard setting committee.

On appeal, Rambus challenged the FTC on two grounds:

First, it argues that the Commission erred in finding that it violated any JEDEC patent disclosure rules and thus that it breached any antitrust duty to provide information to its rivals. Second, it asserts that even if its nondisclosure contravened JEDEC's policies, the Commission found the consequences of such nondisclosure only in the alternative: that it prevented JEDEC either from adopting a non-proprietary standard, or from extracting a RAND ${ }^{29}$ commitment from Rambus when standardizing its technology. As the latter would not involve an antitrust violation, says Rambus, there is an insufficient basis for liability.

${ }^{27}$ Rambus, Inc. v. FTC, __ F.3d__, 2008 WL 1795594 (D.C.Cir. April 22, 2008).

${ }^{28}$ See the discussion supra.

29"RAND" means "reasonable and nondiscriminatory" license terms. See Mark R. Patterson, Inventions, Industry Standards, and Intellectual Property, 17 Berkeley Tech. L.J. 1043, 1053-54 (2002), which explores the concept and notes definitional problems. Typically, the problem is not the "nondiscriminatory" requirement, which simply means that all licensees get the same terms, but rather determining how large a royalty is appropriate. See also Janice M. Mueller, Patenting Industry Standards, 34 J. Marshall L. Rev. 897 (2001). 
The court found the second of these arguments to be persuasive. ${ }^{30}$ Mainly, the Commission found, in the alternative that absent the misrepresentations JEDEC would either have adopted a non-proprietary standard or else extracted a RAND commitment from Rambus. However, the Commission had not determined that one of these or the other would have occurred. The court "assumed[d] without deciding" that the first alternative would have been anticompetitive. ${ }^{31}$ However, the Commission itself had recognized that there was insufficient evidence in the record that JEDEC "would have standardized other technologies had it known the full scope of Rambus's intellectual property." ${ }^{12}$ Absent such a showing all the Commission had was an act of "deceptive conduct," which is insufficient to establish an antitrust violation:

Even if deception raises the price secured by a seller, but does so without harming competition, it is beyond the antitrust laws' reach. Cases that recognize deception as exclusionary hinge, therefore, on whether the conduct impaired rivals in a manner tending to bring about or protect a defendant's monopoly power. In Microsoft, for example, we found Microsoft engaged in anticompetitive conduct when it tricked independent software developers into believing that its software development tools could be used to design crossplatform Java applications when, in fact, they produced Windows-specific ones. The deceit had caused "developers who were opting for portability over performance . . . unwittingly [to write] Java applications that [ran] only on Windows." ${ }^{33}$ The focus of our antitrust scrutiny, therefore, was properly placed on the resulting harms to competition rather than the deception itself. ${ }^{34}$

\footnotetext{
${ }^{30}$ Rambus, F.3d at

${ }^{31}$ Id. at

${ }^{32}$ Id. at

${ }^{33}$ Citing and quoting Microsoft, note 16, 253 F.3d at 76.
}

${ }^{34}$ Rambus, _ F.3d at _. The court also discussed Conwood Co. v. U.S. Tobacco Co., 290 F.3d 768 (6th Cir. 2001), cert. denied, 537 U.S. 1148 (2003); and LePage's, Inc. v. 3M, 324 F.3d 141, 153 (3d cir. 2002), cert. denied, 542 U.S. 953 (2004). 
In contrast, the Supreme Court's NYNEX decision made clear that even a fraudulent agreement leading to higher prices is not inevitably an antitrust violation. The challenger must show harm "not to a single competitor, but to the competitive process." ${ }^{35}$ Further, any price increase must flow from an unlawful exercise of market power, not just from the deception. ${ }^{36}$ Here, "the Commission expressly left open the likelihood that JEDEC would have standardized Rambus's technologies even if Rambus had disclosed its intellectual property." ${ }^{37}$ It continued:

Under this hypothesis, JEDEC lost only an opportunity to secure a RAND commitment from Rambus. But loss of such a commitment is not a harm to competition from alternative technologies in the relevant markets. "[A]n antitrust plaintiff must establish that the standard-setting organization would not have adopted the standard in question but for the misrepresentation or omission. ${ }^{38}$ Indeed, had JEDEC limited Rambus to reasonable royalties and required it to provide licenses on a nondiscriminatory basis, we would expect less competition from alternative technologies, not more; high prices and constrained output tend to attract competitors, not to repel them. ${ }^{39}$

${ }^{35}$ Referring to NYNEX Corp. v. Discon, Inc., 525 U.S. 128, 135 (1998).

${ }^{36}$ Rambus, _ F.3d at __ citing NYNEX, id., and noting the rate regulation avoidance consumer fraud scheme that motivated the arrangement; and also citing $3 \mathrm{~A}$ Antitrust Law $\$ 787 \mathrm{~b}$ in the previous edition. The court also cited, with this parenthetical: Forsyth v. Humana, Inc., 114 F.3d 1467, 1477-78 (9th Cir. 1997) (rejecting a claim that an insurance company's alleged kickback scheme caused antitrust injury to group health insurance customers where the evidence showed the scheme caused higher copayments and premium payments, but did "not explain how the scheme reduced competition in the relevant market"), aff'd on other grounds, 525 U.S. 299 (1999).

${ }^{37}$ Rambus, __ F.3d at ___ (emphasis in original).

${ }^{38}$ Quoting 2 Herbert Hovenkamp, Mark D. Janis, Mark A. Lemley, and Christopher Leslie, IP \& Antitrust §35.5 at 35-45 (2d ed. 2010).

${ }^{39}$ Rambus, __ F.3d at __. The court continued:

Scholars in the field have urged that if nondisclosure to an SSO enables a participant to obtain higher royalties than would otherwise have been attainable, the "overcharge can properly constitute competitive harm 
Thus, the court concluded, if JEDEC would have adopted Rambus' technology anyway, but for the deception, although perhaps at a lower royalty rate, then the deception did not injure competition. As a result, the Commission failed to demonstrate that Rambus' conduct was exclusionary, as ' 2 required.

The court also noted the possibility that a standalone action under ' 5 of the FTC Act for deception would have had a "broader province" than a Sherman Act action. ${ }^{40}$ However, it expressed "serious concerns" about the strength of any evidence of deception involving violation of JEDEC's admittedly ambiguous patent disclosure policies. In this case any relevant nondisclosure requirement would have applied to disclosure of Rambus's "work in progress on potential amendments to pending applications, as that work became pertinent." 41 Indeed, it seemed clear that at the time of Rambus' last involvement with JEDEC it "had no pending patent claims that would necessarily have been infringed by a device compliant with that [JEDEC] standard." ${ }^{42}$ This made the case for deception turn on the view that Rambus had a duty, not merely to disclose current patents and patent applications, "but also their work in progress on amendments to pending applications that included new patent claims." ${ }^{43}$ The Commission's evidence did not show that

attributable to the nondisclosure," as the overcharge "will distort competition in the downstream market." 2 IP \& Antitrust ' 35.5 at 35-47. The contention that price-raising deception has downstream effects is surely correct, but that consequence was equally surely true in NYNEX (though perhaps on a smaller scale) and equally obvious to the Court. The Commission makes the related contention that because the ability to profitably restrict output and set supracompetitive prices is the sine qua non of monopoly power, any conduct that permits a monopolist to avoid constraints on the exercise of that power must be anticompetitive. But again, as in NYNEX, an otherwise lawful monopolist's end-run around price constraints, even when deceptive or fraudulent, does not alone present a harm to competition in the monopolized market.

\footnotetext{
${ }^{40}$ Rambus, _ F.3d at __.

${ }^{41}$ Rambus, __ F.3d at __.

${ }^{42}$ Id. at

${ }^{43}$ Id. at
} 
JEDEC's disclosure requirements were so broad as to apply to unfiled patent amendment applications, although some witnesses may have believed so. The court's own perusal of JEDEC's written policies could find language speaking "fairly clearly of disclosure obligations related to patents and pending patent applications." However there was apparently "nothing of unfiled work in progress on potential amendments to patent applications." The court expressed doubt that a "few strands of trial testimony" could make the Commission conclude that these policies should be interpreted more broadly. ${ }^{44}$ Problematically, "JEDEC's patent disclosure policies suffered from a 'staggering lack of defining details."'45 Beginning with the observation that unpublished continuing patent applications are trade secrets, the court observed:

One would expect that disclosure expectations ostensibly requiring competitors to share information that they would otherwise vigorously protect as trade secrets would provide clear guidance and define clearly what, when, how, and to whom the members must disclose. ${ }^{46}$ This need for clarity seems especially acute where disclosure of those trade secrets itself implicates antitrust concerns; JEDEC involved, after all, collaboration by competitors. ${ }^{47}$ In any event, the more vague and muddled a particular expectation of disclosure, the more difficult it should be for the Commission to ascribe competitive harm to its breach. ${ }^{48}$

\footnotetext{
${ }^{44}$ Id. at
}

${ }^{45}$ Rambus, _ F.3d at __, quoting Rambus Inc. v. Infineon Technologies AG, 318 F.3d 1081, 1102 (Fed.Cir.2003).

${ }^{46}$ Citing Infineon, note 8, 318 F.3d at 1102.

${ }^{47}$ Citing, with these parentheticals: Allied Tube \& Conduit Corp. v. Indian Head, Inc., 486 U.S. 492, 500 (1988) (stating that because SSO members have incentives to restrain competition, such organizations have traditionally been objects of antitrust scrutiny ); Am Soc'y of Mech. Eng'rs v. Hydrolevel Corp., $456 \mathrm{U}$ .S. 556, 571 (1982) (noting that SSOs are rife with opportunities for anticompetitive activity).

${ }^{48}$ Citing 2 IP \& Antitrust, note 38 , at ' 35.5 at 35-51 ("[A]lthough antitrust can serve as a useful check on abuses of the standard-setting process, it cannot substitute for a general enforcement regime for disclosure rules."). 


\section{Breach of Promise: the Broadcom Decision}

In its Broadcom decision the Third Circuit held that the plaintiff stated a claim that the defendant's alleged deceptions before a standard-setting organization monopolized markets for cellular phone technology and components. ${ }^{49}$ Both parties participated in a standard-setting organization called ETSI (European Telecommunications Standards Institute) that was in part intended to establish increased compatibility among cellphone systems. ETSI required its vendor members to commit to licensing any intellectual property rights (IPRs) they might hold that are adopted in a standard to be licensed to others on fair, reasonable, and non-discriminatory

${ }^{49}$ Broadcom Corp. v. Qualcomm Inc., 501 F.3d 297 (3d Cir. 2007).

See also Negotiated Data Solutions, 2008 WL 258308 (FTC, Jan. 22, 2008). The FTC complained that the respondent Negotiated Data Solutions LLC ("N-Data") reneged on a promise made during the course of its participation in a standard setting procedure that it would license its technology at a low rate. The dispute involved two acquired patents in the ethernet field. Before the patents were transferred the transferor had made written promises to license the technology for a flat rate of $\$ 1000$, and all parties to the transfer were aware of these prior commitments. Then after the standard setting organization adopted the standard and became "locked in" to it, the firm insisted on royalties that were many times higher. The respondent settled, but the decision produced a 3-2 split on the question of market power and also on the reach of ' 5 of the FTC Act. The majority found an "unfair method of competition" under ' 5 mainly because of the lock-in and the fact that the deception would lead to higher prices in the product markets affected by the technology, citing Herbert Hovenkamp, Federal Antitrust Policy; the Law of Competition and its practice 596-597 (3d ed. 2005) for application of ' 5 when "(1) the practice seems anticompetitive but is not technically covered by the antitrust laws, and (2) the social cost of an error seems to be relatively small." The dissenters also feared private lawsuits under state or federal law in the wake of the FTC consent decree, but the majority made a point of noting that its holding was strictly under ' 5 , which contains no private right of action, and not under the Sherman or Clayton Acts. On the distinction, see 2 Phillip E. Areeda \& Herbert Hovenkamp, Antitrust Law $\$ 302 \mathrm{~h}$ (3d ed. 2007). In particular, Commissioner Kovacic was concerned that, while no private federal antitrust action would lie, some private plaintiffs might find state law more hospitable. The majority concluded:

We recognize that some may criticize the Commission for broadly (but appropriately) applying our unfairness authority to stop the conduct alleged in this Complaint. but the cost of ignoring this particularly pernicious problem is too high. using our statutory authority to its fullest extent is not only consistent with the Commission's obligations, but also essential to preserving a free and dynamic marketplace. 
("FRAND") terms. Broadcom alleged that ETSI adopted Qualcomm's proprietary technology in its standards "only after, and in reliance on, Qualcomm's commitment to license that technology on FRAND terms." ${ }^{50}$ The alleged violation was that Qualcomm demanded:

discriminatorily higher (i.e., non-FRAND) royalties from competitors and customers using chipsets not manufactured by Qualcomm. Qualcomm, the Complaint continued, has a $90 \%$ share in the market for CDMA-path chipsets, and by withholding favorable pricing in that market, coerced cellular telephone manufacturers to purchase only Qualcommmanufactured UMTS-path chipsets. ${ }^{51}$

In finding a possible ' 2 violation the court observed that standard-setting is generally procompetitive and benefits not only the assemblers and users of technology but also their suppliers, enabling them to produce large volumes of a product with less risk that they are committing themselves to a technology that might not attain widespread acceptance. ${ }^{52}$ As the court observed, while standard setting might be viewed as a competitively suspicious arrangement that limits competition for different technologies, it in fact switches the focus of competition toward price. ${ }^{53}$

This is not to say, however, that acceptance, including judicial acceptance, of private standard setting is without limits. Indeed, that "private standard-setting by associations comprising firms with horizontal and vertical business relations is permitted at all under the antitrust laws [is] only on the understanding that it will be conducted in a nonpartisan manner offering procompetitive benefits," and in the presence of "meaningful safeguards" that "prevent the standard-setting process from being biased by members with economic interests in stifling product competition...." ${ }^{54}$

${ }^{50}$ Id. at 304.

${ }^{51}$ Id. at 304.

${ }^{52}$ Id. at 309, citing vols. 1 and 12 Antitrust Law $\Upsilon$ \100a, 2233.

${ }^{53} 501$ F.3d at $309 \&$ n. 4 .

${ }^{54}$ Id. at 309 , quoting Allied Tube, note 47, 486 U.S. at 506-07, which it 
However, the standard setting process could be undermined by what the court termed "patent hold-up:"

An SDO ("standard-determining organization") may complete its lengthy process of evaluating technologies and adopting a new standard, only to discover that certain technologies essential to implementing the standard are patented. When this occurs, the patent holder is in a position to "hold up" industry participants from implementing the standard. Industry participants who have invested significant resources developing products and technologies that conform to the standard will find it prohibitively expensive to abandon their investment and switch to another standard. They will have become "locked in" to the standard. In this unique position of bargaining power, the patent holder may be able to extract supracompetitive royalties from the industry participants. ${ }^{55}$

It observed that:

Private standard setting occurs in a consensus-oriented environment, where participants rely on structural protections, such as rules requiring the disclosure of IPRs, to facilitate competition and constrain the exercise of monopoly power. In such an environment, participants are less likely to be wary of deception and may not detect such conduct and take measures to counteract it until after lock-in has occurred. At that point, the resulting harm to competition may be very difficult to correct. ${ }^{56}$

The court then analyzed as follows. Most SDOs require participants in the process either to disclose IPRs or to commit to license any IPRs incorporated into the standard on FRAND terms, or both. This commitment then guides decision making within the SDO because it enables the members to evaluate the costs of alternative

described as holding that "conduct that undermines the procompetitive benefits of private standard setting may, at least in some circumstances, be deemed anticompetitive under antitrust law."

${ }^{55} 501$ F.3d at 310.

${ }^{56}$ Id. at 312. 
technologies prior to any commitment and lock-in. ${ }^{57}$ At this time "[m]isrepresentations concerning the cost of implementing a given technology may confer an unfair advantage and bias the competitive process in favor of that technology's inclusion in the standard." ${ }^{58}$

The court then noted that a standard "by definition, eliminates alternative technologies" and can make one particular set of technologies much more valuable than alternative sets that are not adopted. ${ }^{59}$ So the reasoning on a ' 2 complaint was like this: first, ex ante, the SDO might have adopted any one of several standards, and in doing so would consider their cost, including the cost of any necessary IPR licensing. Second, by misrepresenting its intentions the defendant biased this process so as to exclude alternative technologies that might otherwise have been selected, and in the process raised costs to licensees, and thus presumably also to consumers. ${ }^{60}$ The court then held that:

${ }^{57}$ Id. at 313 ("The FRAND commitment, or lack thereof, is, moreover, a key indicator of the cost of implementing a potential technology").

${ }^{58}$ Ibid.

${ }^{59}$ Id. at 314. Speaking of Broadcom, the D.C. Circuit's Rambus opinion stated:

There the court held that a patent holder's intentionally false promise to a standard setting organization that it would license its technology on RAND terms, "coupled with [the organization's] reliance on that promise when including the technology in a standard," was anticompetitive conduct, on the ground that it increased "the likelihood that patent rights will confer monopoly power on the patent holder." To the extent that the ruling (which simply reversed a grant of dismissal) rested on the argument that deceit lured the SSO away from non-proprietary technology, it cannot help the Commission in view of its inability to find that Rambus's behavior caused JEDEC's choice; to the extent that it may have rested on a supposition that there is a cognizable violation of the Sherman Act when a lawful monopolist's deceit has the effect of raising prices (without an effect on competitive structure), it conflicts with NYNEX.

Rambus, note 27, __ F.3d at _ , speaking of NYNEX, note 35.

${ }^{60}$ See id. at 314 , also observing:

The patent holder's IPRs, if unconstrained, may permit it to demand supracompetitive royalties. It is in such circumstances that measures such as FRAND commitments become important safeguards against monopoly power. 
(1) in a consensus-oriented private standard-setting environment, (2) a patent holder's intentionally false promise to license essential proprietary technology on FRAND terms, (3) coupled with an SDO's reliance on that promise when including the technology in a standard, and (4) the patent holder's subsequent breach of that promise, is actionable anticompetitive conduct. $^{61}$

The Third Circuit noted the defendant's argument that antitrust liability should not turn on a concept so vague as whether royalties are "reasonable," given the wide room for interpretation as to whether a particular royalty is reasonable. The court might have added that in this case the claim was not simply that the royalty was "unreasonable" in the abstract, but that it was discriminatory in the sense that competitor and customers of the defendant were allegedly charged more if they used technology (chipsets) that was not manufactured by Qualcomm. ${ }^{62}$ That particular claim, if proven, is much easier to analyze than a claim whether a royalty of a certain percentage is reasonable. Whatever its absolute size, a nondiscriminatory royalty is one that is the same to all customers covered by the RAND obligation. Further, equity relief need be no more complex than forcing the firm to charge the same royalty to all consistent with its prior obligation. Whether such relief ought to come under the antitrust laws is a different issue.

On the exclusionary practice analysis the court concluded that the complaint:

... adequately alleged that Qualcomm obtained and maintained its market power willfully, and not as a consequence of a superior product, business acumen, or historic accident. Qualcomm excluded competition and refused to compete on the merits. As discussed above, the

Citing Daniel G. Swanson \& William J. Baumol, Reasonable and Nondiscriminatory (RAND) Royalties, Standards Selection, and Control of Market Power, 73 Antitrust L.J. 1, 5, 10-11 (2005).

${ }^{61}$ Id. at 314.

${ }^{62}$ See 501 F.3d at 304. 
alleged anticompetitive conduct was the intentional false promise that Qualcomm would license its WCDMA technology on FRAND terms, on which promise the relevant SDOs relied in choosing the WCDMA technology for inclusion in the UMTS standard, followed by Qualcomm's insistence on non-FRAND licensing terms. Qualcomm's deceptive conduct induced relevant SDOs to incorporate a technology into the UMTS standard that they would not have considered absent a FRAND commitment. ${ }^{63}$

The court also rejected the complaint of the defendant and some amici that the complaint was of refusal to deal by another name, and that the court was simply being asked to extend the reasoning of unilateral refusal to deal cases. The court noted that this could not be an attempt to apply refusal-to-deal law in conflict with the Supreme Court's Trinko decision ${ }^{64}$ to circumstances where the parties had no prior relationship. ${ }^{65}$ Rather,

... Qualcomm is alleged to have actively marketed its WCDMA technology for inclusion in an industry-wide standard, and to have voluntarily agreed to license that technology on FRAND terms. We note, albeit in passing, that the Court in Verizon pointed as well to the extensive regulatory framework that created oversight functions and remedies that the antitrust laws were unsuited to augment. No such regulatory framework exists here. ${ }^{66}$

The court also rejected the argument that "monopoly" is the inevitable result of a standard setting process because a single standard is chosen and this was really no more than a dispute about who should own that standard. As the court noted, however, nothing in the complaint suggested that the participants could not have adopted a non-proprietary technology in which royalties or

${ }^{63} 501$ F.3d at 315 .

${ }^{64}$ Referring to Verizon Communications, Inc. v. Law Offices of Curtis Trinko, LLP, 540 U.S. 398 (2004).

${ }^{65}$ On this point, see 3B Antitrust Law $\llbracket 772 \mathrm{e}(3 \mathrm{~d}$ ed. 2008).

${ }^{66}$ Id. at 316-317, discussing Trinko, 540 U.S. at 404-410. 
exclusionary power would not be owing to anyone. ${ }^{67}$ And, of course, prices would be lower if they had adopted the technology of a firm that promised a lower royalty and then adhered to its promise.

\section{Conclusion}

While deception about one's IP rights or intentions in the course of participating in standard setting is reprehensible conduct, not much of it constitutes a violation of ' 2 of the Sherman Act. As the D.C. Circuit noted in Rambus, such a violation requires some kind of "exclusion" and not merely higher prices such as might result from fraud in a transaction.

\$ Rambus poses difficulties for two reasons. First, the patent continuation process of which Rambus availed itself is fully sanctioned by the Patent Office and the Federal Circuit, notwithstanding that we might find many of its features to be anticompetitive and inimical to the encouragement of innovation. ${ }^{68}$ Second, in Rambus the standard setting organization had been woefully deficient in articulating its disclosure requirements. In the case of clear deception in violation of clearly articulated disclosure requirements we would give the patentee the burden of showing that its deception was non-exclusionary -- that is, that a member later charged with infringement would have adopted the patentee's technology even if the truth had been known. We would not find liability if the deception is not clear because the organization failed to articulate its disclosure requirements, as the Rambus case suggests. The obligation of disclosure runs in both directions. The technology that is subject of a patent continuation may be subject to trade secret protection during the time that a patent application is pending and unpublished, ${ }^{69}$ and the duty to disclose should only be inferred from a clear statement.

${ }^{67}$ Ibid.

${ }^{68}$ See Lemley and Moore article, note 1.

${ }^{69}$ See, e.g., Bond/Pro Corp. v. Siemens Power Generation, Inc., 463 F.3d 702 (7th Cir. 2006). 
$\$$ On the other side, the conduct requirement ${ }^{70}$ for the monopolization offense seems clear if the defendant's misrepresentations induced the SSO to adopt its technology to the exclusion of an alternative technology that would have been preferable.

\$ As to Broadcom, ${ }^{71}$ breach of a promise is only rarely an antitrust violation. The more obvious remedy for breach of a promise to license at a certain rate would be a contract suit, or perhaps use of a doctrine such as equitable estoppel to prevent the defendant from reneging on its promises. Nevertheless, we would apply ' 2 to a situation in which a patentee represents that it would charge a low royalty and later insists on a higher royalty, unless it is clear that the standard setters would have taken the patentee's technology even at the higher rate. If they would not have done so, then the misrepresentation resulted in substitution away from alternative patented technology or technology that was in the public domain. A sequence of (a) deception about one's current or contemplated patent rights; plus (b) the alleged infringer's adoption of the covered technology in reliance on this deception; and then (c) the patentee's announcement in contradiction to the statements in (a) is clearly improper conduct. If accompanied by the structural components of the monopolization offense we would place the burden on the patentee to show that the other party would have adopted the technology even if the misrepresentation had not been made. Presumably that burden could be met by a showing that no suitable alternative technology was realistically available.

\footnotetext{
${ }^{70}$ The structural requirement could be met either by a defendant who was already a monopolist or else by a showing that the deception did or would have lead to the creation of a monopoly. The situation is analogous to monopoly created or perpetuated by a wrongful infringement suit. See 3 Antitrust Law \706a3.
}

\footnotetext{
${ }^{71}$ See note 49.
} 
In a situation such as Broadcom the more marginal case occurs when the alternative technology would have been in the public domain. Suppose, for example, that the members would have been willing to pay $\$ 6$ for the patentee's technology but at any higher price they would have preferred public domain technology. The patentee misleadingly promised that the technology would cost $\$ 6$ or less, but then later charged $\$ 10$. In that case the deception results in higher prices, presumably to customers as well, but is it an "exclusionary" practice. given that no firm controls the public domain? Of course, a fraudulent patent infringement suit can do exactly the same thing. ${ }^{72}$ It may give the patentee a monopoly on something that rightfully belongs in the public domain.

\footnotetext{
${ }^{72}$ See 3 Antitrust Law $\lceil 706$ (3d ed. 2008).
} 